\title{
A MEGEMELKEDETT ÉRZELMI AROUSAL SZEREPE A REKLÁM ÁLTAL BEFOLYÁSOLT VÁSÁRLÁSI DÖNTÉSEKBEN
}

\section{THE ROLE OF THE HIGH EMOTIONAL AROUSAL LEVEL IN PURCHASING DECISIONS CAUSED BY ADVERTISING}

\author{
Molnár Edina ${ }^{1 *}$ \\ 1 Vezetés- és Szervezéstudományi Intézet, Gazdaságtudományi Kar, Debreceni Egyetem, Magyarország \\ https://doi.org/10.47833/2020.2.ART.004
}

\section{Kulcsszavak: \\ empátia \\ szorongás \\ személyiség \\ vásárlási döntés \\ érzelmi arousal}

\section{Keywords:}

empathy

anxiety

personality

purchase decision

emotional arousal

\section{Cikktörténet:}

Beérkezett 2020 február 29.

Átdolgozva 2020. március 20.

Elfogadva 2020. április 10.

\begin{abstract}
Összefoglalás
Az empátia képessége feltétlenül szükséges a mindennapi élethez, az egyszerü mozgásokat sem tudnánk értelmezni empátia nélkül. Elengedhetetlen a gyógyitásban, a tanításban, sőt a modern társadalmak erre építenek a reklámok vagy filmek bemutatásakor.
\end{abstract}

A reklámot fontosnak tartó egyének esetében a szituáció hatásának tünő, pillanatnyi magas arousal okozza a személyes distressz vagy az empátiás aggodalom fellépését, vagy tekinthetjük ezt egy stabil személyiségvonásnak, amely általában jellemző reagálásmódot jelent az empátiát igénylő helyzetekben? Van különbség a fenti kategóriákban azon egyének között, akik - saját bevallásuk szerint - általában a reklámok hatására vásárolnak, és azok között, akik nem érzik a reklám hatásosságát a vásárlási döntéseikben? A cikkben erre a két kérdésre keresem a választ.

\begin{abstract}
The ability to empathize is essential to everyday life, and we cannot interpret simple movements without empathy. It is essential in healing, teaching, and even modern societies rely on it for commercials or films.

For individuals who consider advertising important, does the seemingly high arousal of personal distress or empathic anxiety appear to be the effect of the situation, or can it be considered a stable personality trait that usually represents a response in situations requiring empathy? Is there a difference in the above categories between individuals who, according to their own admission, tend to buy through advertising and those who do not feel the effectiveness of advertising in their purchasing decisions? In this article, I seek answers to these two questions.
\end{abstract}

\footnotetext{
* Kapcsolattartó szerző. Tel.: +36 56510300

E-mail cím: molnar.edina.phd@econ.unideb.hu
} 


\section{Bevezetés}

A vásárlási döntést befolyásoló egyik tényező a vásárló személyisége. Elterjedt a vásárlási döntések kommunikációs folyamatként való leírása és elemzése [17], illetve egyéb, a családot elötérbe állító modellek $[9,10,18]$ is jelen vannak, vagy a személyiség egy aspektusát figyelembe vevő operacionalizált kutatások. [1,13] Kevés szó esik azonban a vásárlói személyiségről, vagy azt általában egyoldalúan értelmezik, kevés figyelmet fordítva a személyiség mélyebb pszichológiai elemzésére.

A marketingkutatásban jellemzően két területen jelenik meg az empátia, vagyis a beleérzőképesség vizsgálata. Az egyik terület a személyes eladás, ahol a szolgáltatást vagy árut igénybe vevők, illetve kínálók empatikus hozzáállásának hatását vizsgálják az eladási folyamatra. $[2,8,14,19,21]$

A másik terület az eleve empátiára építő jótékonysági hirdetések területe. [3,11,20]

Kohut szerint [12] az empátia segítségével a másik ember egy intuitív benyomást tesz ránk, amely folyamatában az arcfelismerés hirtelen, nem szándékos, intuitív jellegéhez hasonlítható. Az empátiás ráhangolódás és az arcfelismerés közös jellege Kohut szerint a korai anya-gyermek kapcsolatban gyökerezik és innen indul fejlődésnek.

Az empátia képessége feltétlenül szükséges a mindennapi élethez: Kohut szerint az egyszerü mozgásokat sem tudnánk értelmezni empátia - és intrapszichikus megfelelője, az introspekció nélkül. Elengedhetetlen a gyógyításban, a tanításban, sőt a modern társadalmak erre építenek a reklámok vagy filmek bemutatásakor.

A XIX-XX. század társadalmi berendezkedései az egyének elidegenedését eredményezik. Minden automatizálódik és felgyorsul, így egyre kevesebb idő és energia marad az emberi kapcsolatok ápolására. A mindennapi rohanásban az empátia az, ami összekötheti az embereket és biztonságot adhat a kapcsolatok összetartása révén. [7]

Saját vizsgálatomat Kohut azon meglátása inspirálta, hogy a mindennapi élet elengedhetetlen feltétele az empátia, amelyet a reklámok is kihasználnak. A vizsgálatomhoz három adalék szolgál alapul. Egyrészt a segítő viselkedés folyamatmodelljéböl az empátiás gerjedelem [16] és az a megállapítás, hogy a magasabb arousal nagyobb mérvű segítségnyújtáshoz vezet. [4] Másrészt ehhez kapcsolódóan Hebb ismert görbéje [9] az ingerek viselkedést irányító hatékonyságának és az arousalszintnek az összefüggéséröl: az arousalszint további emelkedése az optimális szint után már érzelmi zavart okoz. Harmadrészt pedig Davis eredményei a személyes distressz korrelációival kapcsolatban. [6]

Kérdésfeltevésem az, hogy a reklámot saját magukra nézve fontos vásárlási tényezőként tekintő egyének személyes distressze - azaz a másik ember szenvedésének átélése közben keletkezett megemelkedett arousalja - együtt jár-e a mindennapi élethelyzetekben fellépő emocionális labilitással. Vagy másképp: a reklámot fontosnak tartó egyének esetében a szituáció hatásának tűnő, pillanatnyi magas arousal okozza-e a személyes distressz vagy az empátiás aggodalom fellépését, vagy tekinthetjük ezt egy stabil személyiségvonásnak, amely általában jellemző reagálásmódot jelentene az empátiát igénylő helyzetekben. Másodszor: van-e különbség a fenti kategóriákban azon egyének között, akik - saját bevallásuk szerint - általában a reklámok hatására vásárolnak, és azok között, akik nem érzik a reklám hatásosságát a vásárlási döntéseikben.

\section{Módszer}

\subsection{Vizsgálati személyek}

A kutatás első szakaszában 1864 felnőttel vettem fel kérdőívet. A kérdőív eredményei alapján a vizsgálati személyeket két csoportra osztottam, az első csoport úgy nyilatkozott, hogy nem érzi döntő tényezőnek, a másik csoport viszont kiemelte befolyásoló tényezőként a reklámokat a vásárlási döntései során. Egy korábbi publikációmban [15] ez utóbbi csoport vizsgálatának folyamatát és eredményeit mutattam be, a csoport elemszáma 965 fő volt. Jelen cikkemben az első csoport - a reklámot figyelmen kívül hagyók - eredményeit mutatom be, az elemszám 899 fö, valamint a két csoport összehasonlítását. 


\subsection{Eszközök}

Az empátia és a szorongás mérésére Davis IRI skáláját alkalmaztam. [6] A vizsgálati személyeknek 28 állításról kellett eldönteniük, hogy mennyire jellemzi őket és ezt egy ötfokú skálán jelezni $(0=$ nem jellemző, $4=$ nagyon jellemző $)$. A kérdőív egyaránt tartalmaz egyenes és fordított állításokat. Az állításokra adandó pontszám a személy által adott számokkal egyenlő. Az alskálákat külön kell összegezni. Minden alskála hét állítást tartalmaz, így 0-28 pont adható.

A személyiséget a Big Five személyiségteszttel mértem. [5] A 132 tételes kérdőívre az egyetértés öt fokozatával kellett válaszolni, a pontozás megegyezik az elöbbiekben leírtakkal. Az öt személyiségfaktort a szerzők két-két alskálára bontották, valamint hozzátettek egy szociális kívánatosságot mérő skálát is, amely a vizsgálati személy azon hajlandóságát mutatja, hogy mennyire torzítja a magáról kialakított képet a másoknak való megfelelni vágyás szükséglete. Minden alskála 12 tételből áll.

\subsection{Eljárás}

A két kérdőívet egy alkalommal vettem fel az egyes vizsgálati személyekkel, először a Big Five-ot, utána az IRI-t. Mindkét kérdőíven szerepel a kitöltés instrukciója, a vizsgálati személy egyedül tölti ki a válaszlapokat.

\section{Eredmények}

Az első csoport - a reklámot figyelmen kívül hagyók - esetében az egyes alskálákon elért átlageredmények és szórások a következők:

1. táblázat: A reklámot figyelmen kívül hagyó csoport átlagai és szórásai

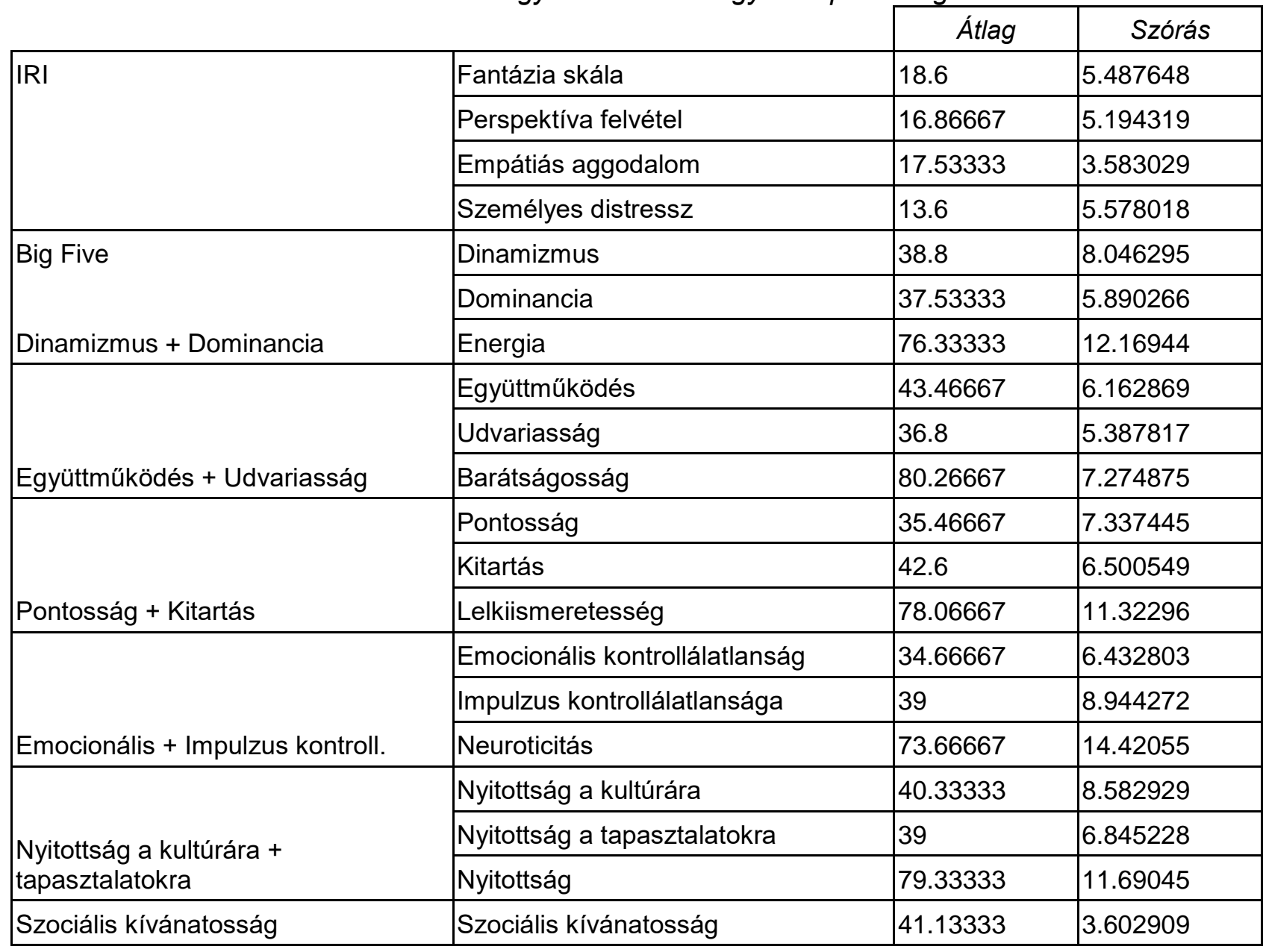

Az IRI kérdőív alskáláit korreláltattam a Big Five alskáláival. A korrelációk a következőképpen alakultak az IRI és a felosztott Big Five alskálák között: 
2. táblázat: Korrelációk a Big Five és az IRI alskálák között

\begin{tabular}{|c|l|l|l|l|}
\cline { 2 - 5 } \multicolumn{1}{c|}{} & \multicolumn{1}{c|}{ Fantázia } & \multicolumn{1}{c|}{$\begin{array}{c}\text { Perspektíva } \\
\text { felvétel }\end{array}$} & \multicolumn{1}{c|}{$\begin{array}{c}\text { Empátiás } \\
\text { aggodalom }\end{array}$} & \multicolumn{1}{c|}{$\begin{array}{c}\text { Személyes } \\
\text { distressz }\end{array}$} \\
\hline Dinamizmus & 0.313504 & 0.064259 & 0.145186 & -0.63849 * \\
\hline Dominancia & 0.3297 & 0.021167 & 0.1074 & -0.21044 \\
\hline Együttmüködés & -0.16516 & $0.696021^{* *}$ & -0.2191 & -0.29339 \\
\hline Udvariasság & -0.05122 & 0.210819 & $0.457327+$ & 0.149258 \\
\hline Pontosság & -0.15469 & 0.415931 & 0.2697 & 0.210821 \\
\hline Kitartás & 0.243483 & 0.216194 & 0.153948 & 0.198171 \\
\hline Emocionális ktr. & 0.17199 & -0.24512 & $0.5165 *$ & 0.517565 * \\
\hline Impulzus ktr. & 0.404562 & -0.14913 & 0.405647 & 0.324992 \\
\hline Nyitottság a kult. & 0.066727 & -0.32898 & 0.344528 & 0.202906 \\
\hline Nyit. a tapasztal. & 0.188249 & 0.401777 & 0.06407 & -0.37975 \\
\hline
\end{tabular}

$\left(+p<0.1,{ }^{*} p<0.05,{ }^{* *} p<0.01\right)$

Az IRI alskálák és az öt személyiségdimenzió - valamint a szociális kívánatosság - korrelációi:

3. táblázat: Az 5 személyiségdimenzió és az IRI alskálák korrelációi

\begin{tabular}{|c|l|l|l|l|}
\cline { 2 - 5 } \multicolumn{1}{c|}{} & \multicolumn{1}{c|}{ Fantázia } & \multicolumn{1}{c|}{$\begin{array}{c}\text { Perspektíva } \\
\text { felvétel }\end{array}$} & $\begin{array}{c}\text { Empátiás } \\
\text { aggodalom }\end{array}$ & \multicolumn{1}{c|}{$\begin{array}{c}\text { Személyes } \\
\text { distressz }\end{array}$} \\
\hline Energia & 0.366868 & 0.052733 & 0.147979 & $-0.52402^{*}$ \\
\hline Barátságosság & -0.17785 & $0.745764^{* *}$ & 0.153091 & -0.138 \\
\hline Lelkiismeretesség & 0.039544 & 0.393647 & 0.263152 & 0.250386 \\
\hline Neuroticitás & 0.32765 & -0.20184 & $0.482003+$ & 0.432453 \\
\hline Nyitottság & 0.159217 & -0.00627 & 0.290462 & -0.07339 \\
\hline Szociális & 0.393062 & 0.230021 & -0.37662 & -0.413 \\
\hline kivánatosság & & & & \\
\hline
\end{tabular}

$\left(+p<0.1,{ }^{*} p<0.05,{ }^{* *} p<0.01\right)$

Következő lépésként T-próbákat végeztem a két csoport - a reklámot figyelmen kívül hagyók és a fontos tényezőként említők - eredményei között. A t értékek nagy része nem mutatott ki szignifikáns különbséget a megfelelö alskálák között, kivéve hármat. A reklámot fontosként ítélők eredményeinek átlaga szignifikánsan magasabb az Udvariasság és az Emocionális kontrollálatlanság alskálákon, mint az első csoporté, a Szociális kívánatosság alskálán pedig a reklámot figyelmen kívül hagyók átlaga magasabb.

4. táblázat: t-próbák szignifikáns eredményei

\begin{tabular}{|c|l|l|l|}
\cline { 2 - 4 } \multicolumn{1}{c|}{} & \multicolumn{1}{c|}{$\begin{array}{c}\text { Reklámot fontosként } \\
\text { ítélök átlaga }\end{array}$} & $\begin{array}{c}\text { Reklámot figyelmen } \\
\text { kívül hagyók átlaga }\end{array}$ & \multicolumn{1}{c|}{ t érték } \\
\hline Udvariasság & 40.40 & 36.80 & 2.0396 \\
\hline Emocionális Kontr. & 44.15 & 34.66 & 2.9416 \\
\hline Szociális kívánatosság & 38.20 & 41.13 & -2.06468 \\
\hline
\end{tabular}




\section{Következtetések}

A reklámot figyelmen kívül hagyók fenti táblázataiból kitünik, hogy szignifikáns pozitív korreláció áll fenn az Emocionális kontrollálatanság és az Empátiás aggodalom, ill. a Személyes distressz között. Ez azt jelenti, hogy az empátiát igénylő helyzetekben az altruisztikus vagy egoisztikus empátia alkalmazása attól függ - azzal jár együtt -, hogy a megfigyelő személy kontrollja mekkora, azaz általában az érzelmet kiváltó helyzetekben milyen mértékben engedi át magát az érzelmeinek anélkül, hogy kontrollálná azokat. Azokat a személyeket, akik nagy kellemetlenségérzetet vagy empátiás rezonanciát élnek át, a környezetük "érzelmes" vagy fokozott érzelmi és indulati életet élönek jellemezhetik. Ezzel szemben akik nem képesek aggodalomra vagy alacsony a személyes szorongásuk, azokra a magas fokú érzelmi kontrolláltság jellemző. Az összevont Neuroticitás dimenzióban szignifikáns eredmény nem jött ki, csak tendenciaszerű kapcsolat és az is csak az Empátiás aggodalommal.

Szignifikáns pozitív a korreláció az Együttmüködés és a Perspektíva felvétel között és tendenciaszerü a kapcsolat az Udvariasság és az Empátiás aggodalom között. Az udvarias, barátságos személyek empátiás helyzetekben magas fokú altruisztikus empátiát élnek át.

Az Energia - ezen belül a Dinamizmus - negatívan korrelál a Személyes distresszel. Ez az eredmény megerősíti Davis vizsgálatának eredményét, nevezetesen azt, hogy a személyes distressz és az introvertáltság pozitívan korrelál.

Összefoglalva: a Neuroticitás személyiségdimenzión belül az Emocionális kontrollálatlanság korrelál az Empátiás aggodalommal és a Személyes distresszel, az Impulzus kontrollálatlansága azonban nem mutat kapcsolatot. Ennek megfelelően a Neuroticitás tendenciaszerüen jár együtt az elöbbiekkel.

Jelen vizsgálat eredménye újabb adalékot ad Davis eredményeihez és a reklám hatékonyságának kérdéséhez. A reklámot saját bevallásuk szerint figyelmen kívül hagyó egyének csoportjában a bizonytalanság, félénkség és sérülékenység mellett érzelmi kontrollálatlanság jellemzi azokat az egyéneket, akik mások szenvedéseit látva kellemetlenül érzik magukat vagy az altruisztikus empátiájuk értéke magas. Empátiás helyzetben a megemelkedett arousal elégséges vagy túlságosan nagymértékủ szorongást eredményez, az előbbi altruisztikus, az utóbbi egoisztikus empátiához vezet. Ez azonban nem csak egy pillanatnyi állapot, hanem ezeket az egyéneket általánosan jellemzik a szélsőséges érzelmi reagálások.

A két csoport összehasonlításában a reklámot fontosként ítélők udvariasabbak, kevésbé kontrollálják az érzelmeiket és kevésbé akarnak megfelelni a szociális elvárásoknak. Ezen kimutatható különbségek, illetve a korábban jelzett tendenciaszerü kapcsolatok további vizsgálatok elvégzését indokolják a területen, de már ez a vizsgálati eredmény is megmutatja, hogy a vásárlási döntésekben a reklám hatásosságának vizsgálata a személyiség szofisztikáltabb megközelítését igényli, több részterület, pl. az empátia vagy a szorongás vagy egyéb személyiségjellemzők feltárásával.

\section{Irodalomjegyzék}

[1] Agárdi, I. (2019) A tapintás iránti preferencia mediáló hatása a fogyasztó neme, a termék típusa és a csatornaválasztás kapcsolatában. Vezetéstudomány - Budapest Management Review, 50 (1). pp. 70-79. DOI: https://doi.org/10.14267/VEZTUD.2019.01.07

[2] Bahadur, W., Khan, A., Ali, A., Usman, M. (2019) Investigating the Effect of Employee Empathy on Service Loyalty: The Mediating Role of Trust in and Satisfaction with a Service Employee. Journal of Relationship Marketing. DOI: https://doi.org/10.1080/15332667.2019.1688598

[3] Bartsch, A., Kloss, A. (2019) Personalized charity advertising: Can personalized prosocial messages promote empathy, attitude change, and helping intentions toward stigmatized social groups? International Journal of Advertising. pp. 345-363. DOI: https://doi.org/10.1080/02650487.2018.1482098

[4] Batson, D. C., Coke, J. S. (1983) A segítő viselkedés empátiás motivációja. In: Barkóczi I., Séra L. (szerk.) Az emberi motiváció I. Tankönyvkiadó, Budapest, 1988. pp. 299-317.

[5] Caprara, G. V., Barbaranelli, C., Borgogni, L., Perugini, M. (1993) The Big Five Questionnaire: A new questionnaire to access the five factor model. Personality and Individual Differences, 15. pp. 281-288. Magyar változat: Rózsa S. 1995. ELTE

[6] Davis, M. H. (1983) Measuring individual differences in empathy: Evidence for a multidimensional approach. Journal of Personality and Social Psychology, 44. pp. 113-126.

[7] Davis, M. H. (2018) Empathy: A social psychological approach. Routledge, New York DOI: https://doi.org/10.4324/9780429493898 
[8] Delpechitre, D., Rutherford, B. N., Comer L. B. (2019) The importance of customer's perception of salesperson's empathy in selling. Journal of Business \& Industrial Marketing Vol. 34 No. 2, pp. 374-388. DOI: https://doi.org/10.1108/JBIM-03-2017-0073

[9] Hebb, D. O. (1975) A pszichológia alapkérdései. Gondolat, Budapest, pp. 228-233.

[10] Horváthné Kökény A., Bálint Á., Kulcsár P., Oravecz G. (2012) A háztartások pénzügyi döntései: gondoskodjunk a jövőnkről Szolnoki Tudományos Közlemények 16 pp. 20-27.

[11] Keskin, H., Akgün, A, Ayar, H., Etlioglu, T. (2017) Persuasive messages and emotional responses in social media marketing. Journal of Management, Marketing and Logistics. 4. pp. 202-208. DOI: 10.17261/Pressacademia.2017.481

[12] Kohut, H. (1985) Self Psychology and the Humanities. Ed. by Charles B. Strozier. W. W. Norton \& Co., New York \& London

[13] Korpás, Z., Szabó, B. (2019) Az online reklámok közvetlen hatásának vizsgálata a vásárlási döntésekre. Marketing \& Menedzsment 53(2), pp. 31-44. DOI: https://doi.org/10.15170/MM.2019.53.02.03

[14] Máté, Z. (2011) A magyarországi kis- és középvállalkozások marketingszervezetének kialakulása, léte, funkciói. Marketing és menedzsment 45:1 pp. 38-43.

[15] Molnár, E. (2020) (megj. alatt) Az empátia, a szorongás és a személyiség szerepe a reklámok által kiváltott vásárlási döntésekben. ACTA CAROLUS ROBERTUS $10: 1$ (2020)

[16] Pervin, L. A. (1978) Altruizmus. Miért segítenek az emberek és miért nem? In: Barkóczi I., Séra L. (szerk.) Az emberi motiváció I. Tankönyvkiadó, Budapest, 1988. pp. 271-298.

[17] Pólya É. (2018) A családon belüli vásárlási-döntési folyamatok komplex modellje. GRADUS $5: 2$ pp. $117-122$

[18] Szakács, A. (2016) A pénzügyi tudatosság fontossága napjainkban. In: Árpási, Z., Bodnár, G., Gurzó, I. (szerk.) A magyar gazdaság és társadalom a 21. század globalizálódó világában 1. kötet. "30 éves a békéscsabai felsőoktatás" jubileumi konferencia, Békéscsaba, SZIE Gazdasági, Agrár- és Egészségtudományi Kar, pp. 198-203.

[19] Umasuthan, H., Park, O. and Ryu, J. (2017), "Influence of empathy on hotel guests' emotional service experience", Journal of Services Marketing, Vol. 31 No. 6, pp. 618-635. https://doi.org/10.1108/JSM-06-2016-0220

[20] Weiss, J. K., Cohen, E. L. (2019) Clicking for change: the role of empathy and negative affect on engagement with a charitable social media campaign, Behaviour \& Information Technology, 38:12, pp. 1185-1193. https://doi.org/10.1080/0144929X.2019.1578827

[21] Zerbini, C., Vergura, D. and Luceri, B. (2019) How fair-trade claims and emotional empathy affect the consumer's propensity to buy fair chocolate? British Food Journal, Vol. 121 No. 7, pp. 1605-1613. https://doi.org/10.1108/BFJ07-2018-0417 